\title{
Hepatocyte Nuclear Factor 1 Beta Mutation-associated Newborn Onset of Glomerulocystic Kidney Disease: A Case Presentation
}

\author{
Renal Ekojenite Artışı ile Başvuran ve HNF1 Beta Mutasyonuna \\ Bağlı Glomerülokistik Hastalık Saptanan Olgu Sunumu
}

\section{(1) Nilufer GOKNAR1, (1) Melda EKICI AVCI2, (1) Diana UCKARDES1, (1) Emre KELESOGLU1, (1) Kubra TEKKUS ERMIS³, (D) Cengiz CANDAN1}

IIstanbul Medeniyet University Faculty of Medicine, Department of Pediatric Nephrology, Istanbul, Turkey

${ }^{2}$ Istanbul Medeniyet University Faculty of Medicine, Department of Pediatrics, Istanbul, Turkey

${ }^{3}$ University of Health Sciences Turkey, Umraniye Training and Research Hospital, Clinic of Genetics, Istanbul, Turkey

\begin{abstract}
Mutations in hepatocyte nuclear factor-1 beta $(H N F I B)$ are the most commonly identified genetic cause of renal malformations. Heterozygous mutations are associated with renal cysts and diabetes syndrome. Various renal developmental abnormalities and maturity-onset diabetes of the young could be the presenting factors of these mutations. A 10-year-old boy who was evaluated for bilateral cystic kidneys and chronic kidney disease from the newborn period was diagnosed with HNFIB-related glomerulocystic disease by DNA sequencing. The differential diagnosis of autosomal dominant polycystic kidney disease was a diagnostic pitfall. The genetic screening of the family revealed his mother, sister, and brother to have the same mutation. Therefore, genetic diagnosis and counseling are important for cystic kidney diseases not only for formulating the diagnosis and early management plan but also for the diagnosis of potential asymptomatic cases in the family.
\end{abstract}

Keywords: Hyperechogenic kidneys, chronic kidney disease, cystic kidney disease, infant
Received: 30 September 2021

Accepted: 22 November 2021

Online First: 17 December 2021

Corresponding Author

N. Goknar

Istanbul Medeniyet University Faculty of Medicine, Department of Pediatric Nephrology, Istanbul,

Turkey

nilufergoknar@gmail.com ORCID: 0000-0003-4376-1216

\section{Öz}

Hepatosit nükleer faktör IB'yi kodlayan (HNFIB) genindeki mutasyonlar, renal malformasyonların en sık genetik nedenlerinden biridir. Bu gendeki heterozigot mutasyonlar renal kist ve diyabet sendromu ile ilişkilidir. Hastalar; farklı renal gelişimsel anomaliler ve gençlerde görülen erişkin tip diyabet ile başvurabilirler. Bu olgu sunumunda, yenidoğan döneminden itibaren her iki böbrekte kistlerin olması ve kronik böbrek hastalığı nedeniyle takip edilen ve DNA sekanslama yöntemi ile HNFıB ilişkili glomerülokistik hastalık tanısı alan on yaşında erkek hasta anlatılmıştır. Ayırıcı tanıda yer alan otozomal dominant polikistik böbrek hastalığı, genetik analiz ile dışlanmıştır. Aile taramasında annenin, kız kardeş ve erkek kardeşin aynı mutasyona sahip olduğu gösterilmiștir. Kistik böbrek hastalıklarında genetik inceleme ve danıșmanlık. sadece erken tanı ve tedavi için değil, ayrıca ailedeki asemptomatik olguların da tanısı için önemlidir.

Anahtar kelimeler: Renal ekojenite artışı, kronik böbrek yetmezliği, kistik böbrek hastalığı, süt çocuğu

\section{INTRODUCTION}

Mutations in hepatocyte nuclear factor-1 beta (HNFIB, OMIM \# 189907) are the most commonly associated genetic cause of congenital anomalies of the kidney and urinary tract (CAKUT) $)^{1.2}$. HNFIB is involved in embryonic renal development and also plays a role in ureteric bud branching and nephrogenesis. Additionally, HNFIB is a transcription factor that is involved in the gene expression

Cite as: Goknar N, Ekici Avci M, Uckardes D, Kelesoglu E, Tekkus Ermis K, Candan C. HNF-1 Beta Mutation-associated Newborn Onset of Glomerulocystic Kidney Disease: A Case Presentation. Medeni Med J 2021;36:352-368

${ }^{\circledR}$ Copyright 2021 by the Istanbul Medeniyet University / Medeniyet Medical Journal published by Galenos Publishing House. Licenced by Creative Commons Attribution-NonCommercial 4.0 International (CC BY-NC 4.0) 
in the epithelial cells of various other organs, such as the pancreas, liver, and the Mullerian duct ${ }^{3,4}$. This disorder is associated with a wide clinical spectrum of renal developmental anomalies, including renal cysts, familial hypoplastic glomerulocystic kidney diseases, and solitary and horseshoe kidneys. Other systemic findings include pancreatic beta-cell dysfunction that leads to diabetes mellitus, gout, and abnormalities of the liver and genital tract $^{5}$.

Hereditary cystic kidney diseases comprise a complex group of genetic disorders and within the previous years more than 70 genes were identified. The most common causes of hereditary cystic kidney diseases and related genes are autosomal recessive polycystic kidney disease; PKHDI, autosomal dominant polycystic kidney disease; PKD1, PKD2, nephronophtisis; NPHP1, NPHP2, NPHP3, NPHP5, NPHP5, NPHP6, NPHPI1, Bardet Biedl syndrome; BBS and hepatocyte nuclear factor-1 beta nephropathy; $H N F 1 B$. The genetic heterogeneity and absence of a phenotype-genotype correlation is a major challenge for physicians ${ }^{6}$. Herein, we reported the case of a family with HNFIB-associated cystic kidney disease with unusual presentations and the different spectrum of the disease in the family members.

\section{CASE REPORT}

A 10-year-old boy, the first child of nonconsanguineous parents, was prenatally diagnosed with polycystic kidney disease. Postnatal ultrasonography (USG) revealed normal-sized kidneys (right kidney: $46 \times 21 \mathrm{~mm}$ and left kidney: $47 \times 20 \mathrm{~mm}$ ), diffused renal hyperechogenicity, mild hydronephrosis in the left kidney, and bilateral multiple millimetric cysts (3-4 mm). Physical examinations did not identify any extrarenal malformations and blood pressure was normal. Laboratory examination revealed that the serum creatinine level was $1 \mathrm{mg} / \mathrm{dL}(\mathrm{n}=0.5 \pm 0.1)$ at the end of the first week and electrolytes and urine analysis were found to be normal.

At one year of age, the patient was diagnosed with stage 3 chronic kidney disease (CKD). His blood and urine uric acid, liver enzymes, magnesium, and calcium levels were within the normal limits (Table 1). The mother's first USG was normal; however, after three years, an USG detected a simple cyst in the left kidney and laboratory examination showed increased uric acid and creatinine levels, and consequently, she was diagnosed with stage 2 CKD. The father demonstrated normal kidney function and USG findings. Due to a positive family history of renal cysts, a high suspicion of autosomal dominant polycystic kidney disease emerged in the children. In the following years, his mother gave birth to a girl and a boy (Figure 1). His sister and brother also had CKD, renal cysts, and diffused hyperechogenicity in both kidneys. His mother and sister had hyperuricemia and hypomagnesemia. All the family members were checked for diabetes but none were clinically diagnosed. His mother and father

\begin{tabular}{|c|c|c|}
\hline Blood parameters (units) & Value & $\begin{array}{l}\text { Reference } \\
\text { range }\end{array}$ \\
\hline \multicolumn{3}{|l|}{ Age: 1 month } \\
\hline Creatinine (mg/dL) & 0.97 & $(0.5 \pm 0.1)$ \\
\hline Urea $(\mathrm{mg} / \mathrm{dL})$ & 16 & $(15-36)$ \\
\hline Blood glucose (mg/dL) & 88 & $(60-100)$ \\
\hline Sodium $(\mathrm{mEq} / \mathrm{L})$ & 134 & $(134-146)$ \\
\hline Potassium $(\mathrm{mEq} / \mathrm{L})$ & 4.5 & $(3.5-5.2)$ \\
\hline Uric acid (mg/dL) & 3.19 & $(3.5-7.2)$ \\
\hline Calcium (mg/dL) & 11.12 & $(8.8-10.8)$ \\
\hline Magnesium (mg/dL) & 2.26 & $(1.7-2.2)$ \\
\hline \multicolumn{3}{|l|}{ Age: 1 year } \\
\hline Creatinine (mg/dL) & 0.75 & $(0.3-0.45)$ \\
\hline Urea $(\mathrm{mg} / \mathrm{dL})$ & 50 & $(15-36)$ \\
\hline \multicolumn{3}{|l|}{ Age: 5 years } \\
\hline Creatinine $(\mathrm{mg} / \mathrm{dL})$ & 0.71 & $(0.32-0.59)$ \\
\hline Urea $(\mathrm{mg} / \mathrm{dL})$ & 56 & $(15-36)$ \\
\hline \multicolumn{3}{|l|}{ Age: 10 years } \\
\hline Creatinine (mg/dL) & 1.08 & $(0.39-0.73)$ \\
\hline Urea $(\mathrm{mg} / \mathrm{dL})$ & 45 & $(15-36)$ \\
\hline Blood glucose & 88 & $(60-100)$ \\
\hline Uric acid (mg/dL) & 7.8 & $(3.5-7.2)$ \\
\hline Magnesium (mg/dL) & 1.64 & $(1.7-2.2)$ \\
\hline PTH (pg/mL) & 199 & $(18.5-88)$ \\
\hline
\end{tabular}

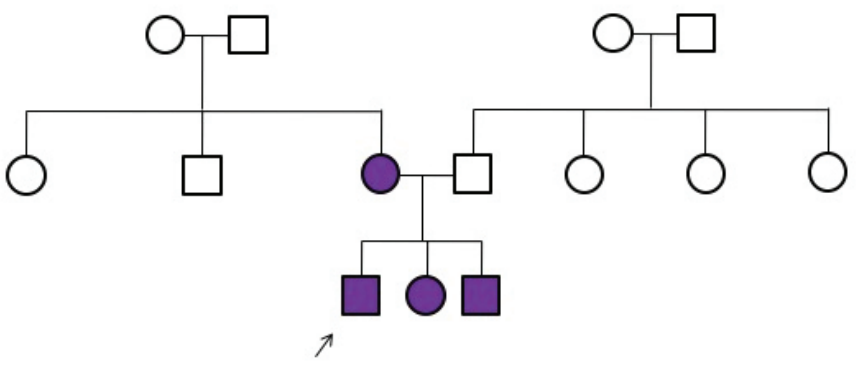

Figure 1. Pedigree of the family affected with hypoplastic glomerulocystic kidney disease, with the proband indicated by an arrow. 
underwent genitourinary system USG, which detected no anomalies.

Written informed consent was obtained from the family, and a renal cysts gene panel, including CEP290, EYA1, OCRL, PKDI, PKD2, PKHDI, SIXI, TTCB2IB, HNFIB, and $C Y P 24 A 1$, was performed. Next-generation sequencing was done, which was confirmed with Sanger's method. A frameshift mutation of the HNFIB gene (NM_000458 gene c.1006dupC [p.His336Profs*24]) was demonstrated in the affected children. Genetic analysis was also performed on the patient's mother, sister, and brother, and the same mutation was found in all of them. The maternal grandfather and grandmother were negative for the mutation, which proved the mother's mutation to be de novo. The father was negative for the mutation.

During the final follow-up visit, the patient was 10 years old with stage 2 CKD, hyperuricemia, hyperparathyroidism, and hypomagnesemia (Table 1). No evidence of diabetes mellitus was found in the patient to date, as assessed by plasma glucose, glycated hemoglobin (HbAlc), and oral glucose tolerance tests.

\section{DISCUSSION}

HNFIB mutations are a major cause of bilateral cystic dysplasia and CKD. Maturity-onset diabetes of the young (MODY), a monogenic form of diabetes mellitus, is associated with HNF mutations. The onset of MODY is usually before 25 years of age and is related to abnormal glucose-stimulated insulin secretion ${ }^{7}$. Herein, we reported the case of a 10-year-old boy who was evaluated for bilateral renal cysts and CKD from the newborn period, and consequently diagnosed with HNFIB mutation (NM_000458 gene c.1006dupC [p.His336Profs*24]). This mutation has been reported in the literature along with the presentation of glomerulocystic kidney disease and early-onset diabetes, HNFIB alterations with CAKUT, and de novo HNFIB gene mutation in familial hypoplastic glomerulocystic kidney disease ${ }^{8.9}$. Autosomal dominant and recessive polycystic kidney disease was excluded by the renal cyst genetic panel. The disease was slowly progressive. The majority of neonates with HNFIB have normal or small-sized kidneys with renal cysts $^{10}$. Various renal abnormalities including dysplastic kidneys and/or hyperechogenicity discovered during fetal life, diabetes mellitus associated with renal cysts, familial oligomeganephronia, renal magnesium wasting, horseshoe and solitary kidney, hyperuricemic nephropathy with gout, and hydronephrosis/hydroureter, have been reported ${ }^{10,11}$. Fortunately, progression to an end-stage kidney disease is rare in childhood ${ }^{12}$.

Hereditary cystic kidney disease comprise comprises a group of slowly progressive disorders, most of which are inherited as an autosomal recessive trait. One important exception is the $H N F I B$ mutation, which has a dominant expression $^{6}$. The expression of $H N F I B$ is significantly variable within the same family and insufficient genotypephenotype correlations have been previously reported ${ }^{13}$. This index case was followed up from the newborn period; however, the first USG of the patient's mother was normal and renal cysts appeared later on. Additionally, hypomagnesemia did not appear until the patient was 10 years old, but his sister and his mother demonstrated apparent hypomagnesemia. The absence of diabetes in the family is surprising as well. The mother's family was evaluated and revealed no mutations. The mutation was hence considered to be de novo, appearing first in the mother. These spontaneous de novo mutations occur relatively frequently (40\%), and thus, testing for $H N F I B$ mutations should be conducted even without a family history of renal disease or diabetes ${ }^{12}$.

During the final follow-up visit, the patient had stage 2 CKD and hyperparathyroidism, which could be either secondary to CKD or HNFIB mutation. The patient did not have hyperphosphatemia and hypocalcemia, which are common biochemical abnormalities in children with early-onset CKD-mineral bone disease ${ }^{14}$. Our clinical impression is that hyperparathyroidism is secondary to HNFIB mutation.

Therefore, the importance of genetic analysis in cystic kidney diseases is increasing. Mutations that cause renal cysts have similar presentations; however, the clinical onset of chronic renal failure significantly differs. Genetic counseling is crucial for the precise diagnosis of patients and close follow-ups are necessary for detecting extrarenal manifestations as well as screening for undiagnosed family members.

\section{Ethics}

Informed Consent: Written informed consent was obtained from the family.

Peer-review: Externally and internally peer-reviewed.

\section{Author Contributions}

Concept: N.G., C.C., M.E.A., Design: N.G., C.C., M.E.A., Data Collection and/or Processing: N.G., C.C., D.U., E.K., M.E.A., K.T.E., Analysis and/or Interpretation: N.G., C.C., 
D.U., E.K., M.E.A., K.T.E., Critical revision: N.G., C.C., M.E.A., Writing: N.G., C.C., D.U., E.K., M.E.A., K.T.E.

Conflict of Interest: The authors declare that they have no conflict of interest.

Financial Disclosure: The authors declared that this study has received no financial support.

\section{REFERENCES}

1. Bockenhauer D, Jaureguiberry G. HNF1B-associated clinical phenotypes: the kidney and beyond. Pediatr Nephrol. 2016;31:707-14.

2. Hwang BY, Dworschak GC, Kohl S, et al. Mutations in 12 known dominant disease-causing genes clarify many congenital anomalies of the kidney and urinary tract. Kidney Int. 2014;85:1429-33.

3. Sields BM, Hicks S, Shepherd MH, et al. Maturity-onset diabetes of young (MODY): how many cases are we missing? Diabetologia. 2010;53:2504-208.

4. Silvia F, Igarashi P. New insights into the role of HNF-1B in kidney patho(physiology). Pediatr Nephrol. 2019;34:1325-35.

5. Edghill EL, Bingham C, Ellard S, Hattersley AT. Mutations in hepatocyte nuclear factor 1 beta and their related phenotypes. J Med Genet. 2006;43:84-90.

6. König JC, Titieni A, Konrad M. Hereditary cystic kidney diseases in childhood. Front Pediatr. 2018;6:24.
7. Horikawa $\mathrm{Y}$, Iwasaki N, Hara M, et al. Mutation in hepatocyte nuclear factor-1 beta gene (TCF2) associated with MODY. Nat Genet. 1997;17:384-5.

8. Nakayama M, Nozu K, Goto Y, et al. HNFIB alterations associated with congenital anomalies of the kidney and urinary tract. Pediatr Nephrol. 2010;25:1073-9.

9. Mache CJ, Preisegger KH, Kopp S, et al. De novo HNF-1 beta gene mutation in familial hypoplastic glomerulocystic kidney disease. Pediatr Nephrol. 2002;17:1021-6.

10. Bellanne-Chantelot C, Chauveau Dominique, Gautier JF, et al. Clinical spectrum associated with hepatocyte nuclear factor-lbeta mutations. Ann Intern Med. 2004;140:510-7.

11. Adalat S, Woolf AS, Johnstone KA, et al. HNFIB mutations associate with hypomagnesemia and renal magnesium wasting. J Am Soc Nephrol. 2009;20:1123-31.

12. Okorn C, Goertz A, Vester L, et al. HNFIB nephropathy has a slowprogressive phenotype in childhood-with the exception of very early onset cases: results of the German Mutlicenter HNFIB Childhood registry. Pediatr Nephrol. 2019;34:1065-75.

13. Heidet L, Decramer S, Pawtowski A, et al. Spectrum of HNFIB mutations in a large cohort of patients who harbor renal diseases. Clin J Am Soc Nephrol. 2010;5:1079-90.

14. Lalayisnnis AD, Crabtree NJ, Fewtrell M, et al. Assessing bone mineralisation in children with chronic kidney disease: what clinical and research tools are available? Pediatr Nephrol. 2020;35:937-57. 